\title{
Motivated word formation and (mis)understanding
}

\section{Kathryn English}

\section{OpenEdition}

\section{Journals}

\section{Electronic version}

URL: http://journals.openedition.org/asp/3709

DOI: 10.4000/asp.3709

ISSN: 2108-6354

\section{Publisher}

Groupe d'étude et de recherche en anglais de spécialité

\section{Printed version}

Date of publication: 1 December 1995

Number of pages: 13-23

ISSN: 1246-8185

\section{Electronic reference}

Kathryn English, « Motivated word formation and (mis)understanding », ASp [Online], 7-10 | 1995,

Online since 24 July 2013, connection on 02 May 2019. URL : http://journals.openedition.org/ asp/3709 ; DOl : 10.4000/asp.3709

This text was automatically generated on 2 May 2019.

Tous droits réservés 


\title{
Motivated word formation and (mis)understanding
}

\author{
Kathryn English
}

I would like to express thanks to my thesis advisor, John Humbley at the CTN/CNRS, Université de Paris-Nord, for his many valuable comments.

1 One of the principal characteristics of Language for Specific Purposes is the concatenation of words stemming from the complex concepts named. Although this is required for the precision of specialist communication between the happy few, it can lead to exclusion of the non-initiated unable to identify with the given context of language production or not sharing the same world view (Haraway 1991; Bélanger 1991; Gaudin 1993,1994). One trend in technical writing courses is to rewrite technical documents to make them legible to wider audiences (Jordan 1994). Some terminologists try to use less scientific-sounding words. Communication specialists in the computer industry use readability measures to test the efficiency of user instructions and other how-to-operate documents (Queipo 1986). This paper will first examine implications of the above in terminological work within ESP communication, and the underlying theoretical assumptions will subsequently be discussed.

\section{ESP and the logic of terms and trees}

2 The assumption informing the theory of efficient communication is that scientific communication, just like scientific procedure, should be objective, principled and follow rule-guided procedures. The need for new lexical units is subordinate to new concepts. When the new terminology is not mastered ESP learners and translators alike believe communication breakdown is due to vocabulary-related problems. Only part of this is due to term formation lagging behind conceptual progress. Complex-sounding terms can however occult meaning. 
3 Each field lexicalizes its own concepts and organizes them according to the criteria which appear applicable and logical, coherent with their point of view and description requirements. This reasoning may be misleading in terms of what is logical. Consider, for example the Chinese encyclopaedia contrived by Jorge Luis Borgès. It divided animals into:

a) belonging to the Emperor, b) embalmed, c) tame, d) sucking pigs, e) sirens, f) fabulous, g) stray dogs, h) included in the present classification, i) frenzied, j) innumerable, k) drawn with a very fine camel hair brush, l) et cetera, $\mathrm{m}$ ) having just broken the water pitcher, $n$ ) that from a long way off look like flies.

4 Michel Foucault suggests that this classification scheme is noteworthy because the categories appear inconceivable to us. George Lakoff feels it reflects Western preconceptions of oriental culture. Epistemological categories are durable, shaped by perceptions and precede thought. However, in specialized fields, only the experts "know" what goes where.

5 The user-friendly classification system in the ALCATEL database for telecommunications terminology, ALCTERMS, may seem relevant only to the specialist. It does, however, illustrate multi-dimensional aspects of the field. Decisions determining topic and subtopic categories are negotiated to reflect corporate strategies to optimize production facilities. In ALCTERMS, the four main categories, component, technique, system, and organization are color-coded to facilitate identification, as shown in the figure on the next page.

6 This organization of terms reflects the requirements of one company. It also shows how knowledge organization, even in a precise technical field, is multi-dimensional.

Figure 1: ALCTERMS topic screen

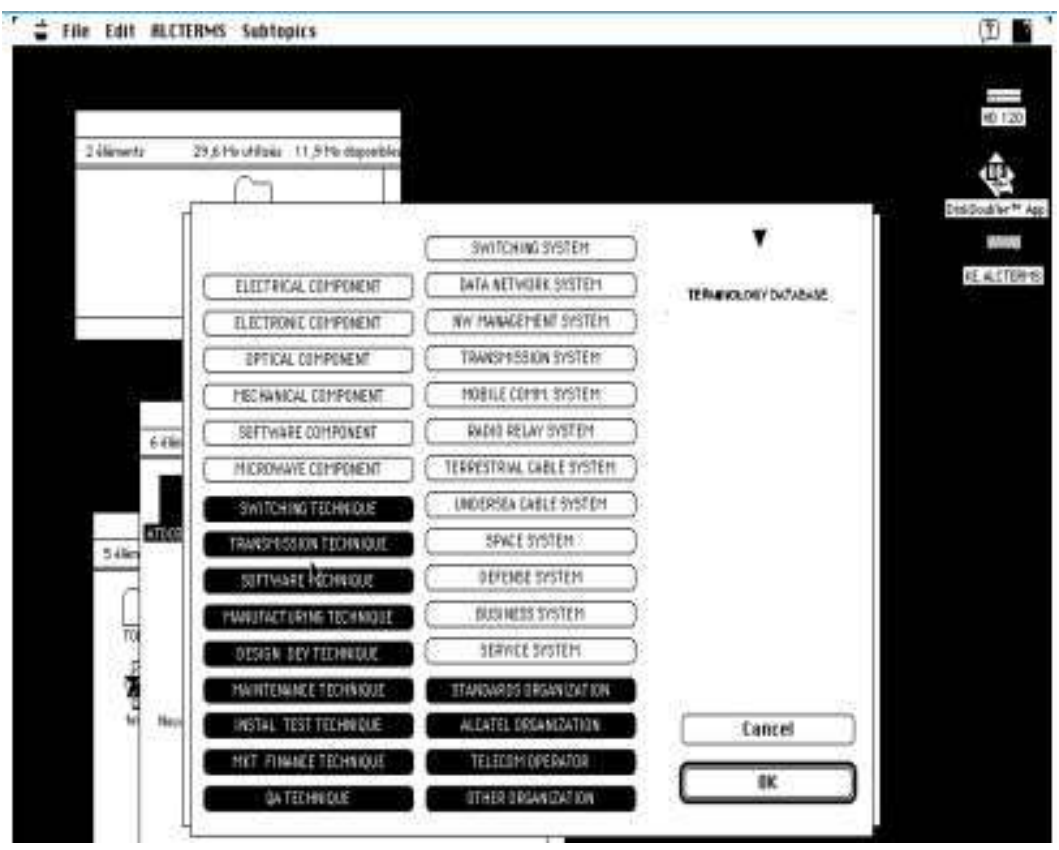

7 Topics are refined by subtopics. Below is an expansion of one category, techniques and one topic, transmission (figure 2). 


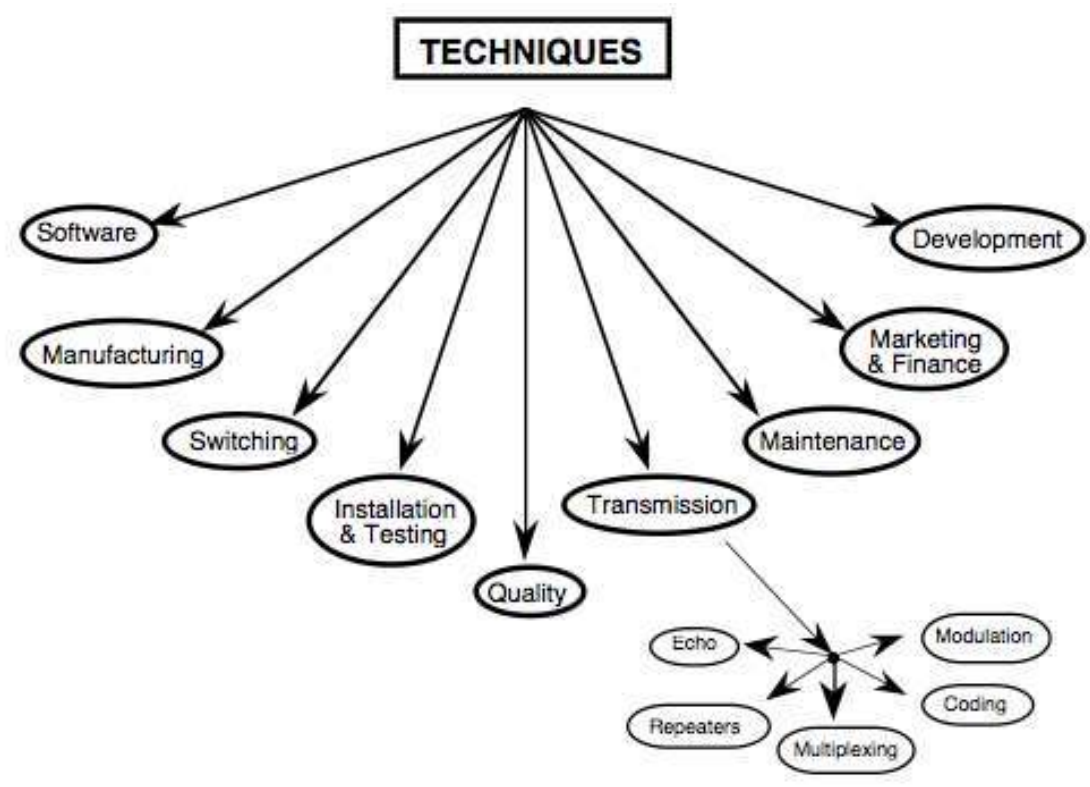

8 As such, our interpretation of the terminological tree's logic should be multi-faceted, not monolithic. Only one form of reality is displayed though diverging realities inhabit the field.

\section{Productive polysemy?}

9 In spite of the categories needed, misconceptions still come about when the same term - a specialised lexical unit - designates different concepts in related subfields. The terminologist delimits the concept and links the term to it.

Consider the word 'semantics' and the meanings it may bear. One dictionary definition is "the scientific study of the relations between signs or symbols and what they denote or mean" (Woods 1975: 41). The Dictionnaire Encyclopédique des Sciences du Langage lists eight references in the index, but none for a neighbouring computer-related field: computational linguistics. In computational linguistics and artificial intelligence, owing to the viewpoint of the computer scientists, semantic information is not only the object denoted but the retrieval and inference capabilities of the computational system. Such divergent interpretations show how meaning is constructed according the differing needs and uses.

11 This case of polysemy can be resolved using the terminologist's main tool-division into categories or fields. For example, the computational linguists partially share the concept "semantics" with the "armchair" linguists and metaphorically refer to information extraction. Natural language polysemy fosters communication between neighboring fields and stimulates creative ideas. Is the onomasiological approach, proned by Wüsterien terminology, from concept to term which strives towards monosemic language, as fertile? 


\section{Metaphorical motivation}

\section{language has to evolve. In the field of telecommur understood metaphoric motivation in mobile communications.}

concept no 1118 : cell (in mobile radio communication)

In a cellular mobile radio communication system, an elementary area to which is assigned a set of radio resources which cannot be reused in contiguous areas. (TLC from J.O. 1468 91) (provisional definition in English - translated from French)

The biological metaphor becomes clear when diagrams showing the honeycomb-like structure chart radio coverage zones.

Figure 3: Schematic representation of a cellular network

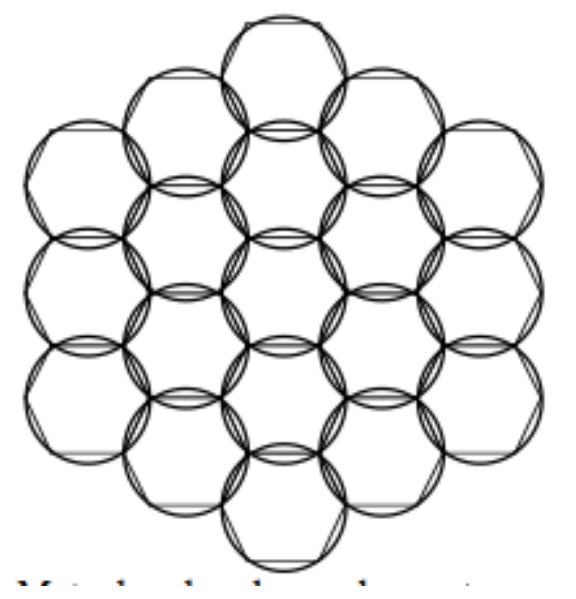

14 Metaphor has been shown to accelerate the assimilation process, and shows how real-life experience enhances our capacity of abstraction or acquisition of new concepts (Corbisier 1994; Stengers 1987; Tournier 1985). A familiar structure guides the cognitive heuristic process. The concept "Cell", however, has advanced to an increasingly abstract meaning in the related, complementary field of switching:

concept no. 325: cell (in ATM)

A block of fixed length, identified by a label at the asynchronous mode layer of the

B-ISDN protocol reference model. (CCITT I.113) (accepted definition)

Figure 4: Schematic representation of a cell in Asynchronous Transfer Mode

\begin{tabular}{|l|l|}
\hline $\begin{array}{c}\text { HEADER }=\text { ADDRESS } \\
5 \text { octets }\end{array}$ & INFORMATION $=48$ octets \\
\hline
\end{tabular}

\section{$1 \mathrm{CELL}=53$ OCTETS}

Although the same metaphor is operational here a different mental representation is evoked. The same analogy motivates the French as well as the English terms. One interesting way of tracking these nomadic metaphors is developed in the Trésor de la Langue Française (TLF). Certain words are rich as metaphors in general language with 
reduced extension in special languages. The TLF gathers different acceptations and lists converging elements of meaning. For example the word cellule has two groups of acceptations under one idée dominante. The first is "l'idée dominante est celle d'espace clos", while the second is "l'idée dominante est celle d'unité morphologique ou fonctionnelle d'un ensemble organize". The distinction between the main ideas is useful when learning about the two concepts, no. 1118 motivated by the first or no. 325 motivated by the second and both lexicalised by cell or cellule.

In the future both fields and functions may be used to make a mobile communications system function. So specialists in both fields will interact with each other and each will understand his own interpretation of the term. Such terminological polysemy can lead to confusion, especially when translators or technical writing specialists, who are one step removed from the concepts, further process texts. This explains the profusion of terminological databases and the need for rigorous classification systems.

The numerous cases of polysemy have progressed unchecked despite increasingly sophisticated efforts at controlling word usage on national levels. Many new terms are created every year. Rules concerning lexical creation are used and abused to fit new realities. Procedures used in writing definitions for terms cannot always be respected. Communication among experts reflecting such positivist philosophy flourishes. The ideology is that one objective way of discussing new concepts coherent with reality exists and should prevail. This attitude ignores how language functions; meaning is constructed through negotiation and is not a predefined given.

\section{Position constructs meaning}

\section{Nationality}

Vehicular English in different countries can produce different meanings. This can be attested to by the growth of projects such as the dictionary of anglicisms (Görlach 1994). In many cases, the same English word has given birth to anglicisms with divergent meanings in different languages. There is no one meaning nor one procedure for going about naming things that meets everyone's needs or reflects everyone's reality (Gaudin 1993; Haraway 1991; Rorty1991). Multinational corporations engage in activities spanning continents and compromise on some form of consensual English to cover communication needs.

\section{Different roles}

The assumption of one objective, concretely motivated way of discussing concepts has been reflected in ESP work and technical writing courses. This assumption appears to be sadly dated. The Philosopher of Science, Paul Feyerabend, has demonstrated how adherence to such well-accepted theories influences the way we interpret raw data. The desire for consistency within proven theories also defines what data is selected and how it is gathered: "...the construction of meaning stems more from prior theory choice than from the data of experience themselves" (Dombrowski 1994: 8). This "objectivity" and respect for rule-bound procedures has had dire consequences in LSP communication.

Studies have been made, for example, into the objectivity and failure of LSP communication in the Challenger disaster (Dombrowski 1994). In this incident, interpretation of data and its meaning was construed from two opposing viewpoints: the Morton Thiokol Incorporated engineers (manufacturer of the defective solid booster 
rockets) and NASA management, which wanted to get a much-delayed flight off the ground. Although the MTI engineers repeatedly insisted that the seals were not flight worthy, past flights during which they had performed adequately led NASA management to underestimate the danger. The language of opposing meanings evolved and has been studied, from tapes of teleconferences over days leading up to the ill-fated lift-off, from the initial "anomalous" to "acceptable erosion", "allowable erosion" and finally "acceptable risk". The raw data was not as significant as the meaning attached to that data. These transcripts show how the notion of "flightworthiness" had divergent values dependent on the context or point of view of the speaker.

This relatively rare study of verbal technical communication illustrates how operational meaning was constructed through participant interaction. Decisions were made on the basis of negotiated (mis)understanding. The content of concretely defined terms was subconsciously renegotiated. Mutually recognized technical characteristics and values had been laid out in NASA standards but they were bypassed in verbal interaction.

\section{From word formation to definition}

Motivation in term formation or word choice is when suffixes or prefixes make meaning apparent. "Objective" criteria, in fact, reflect theoretical choices, ethnic backgrounds, for example the use of Greek or Latin affixes for acceptable neology, or corporate culture where terms can be used as slogans to motivate personnel. Term content and form fluctuate. Consider the case of compiling adequate term records.

Term records usually include both definition and description. A description lists the characteristics of a concept. The definition is a selection of those characteristics which distinguish the concept from all others at the same level of abstraction. This two-fold mechanism can serve to shed light on the notion of objective positivism informing scientific theories, and how this reflects lexical and terminological work.

The technical or scientific approach studies what happens in the conceptual system when a new element is added: what extensions are granted, and how similar concepts are then reorganised or redefined. This form of definition assumes the user knows the field and the message reflects the objective logic of a proposal and how the sender of the message views the conceptual organization of his/her field (terminological or onomaseological view). This objectivist, quasi essentialist view echoes Descartes, Kant or Wüsturieninspired terminology which strives toward monosemic language. Reference is made to the division of discrete entities within a systematically defined conceptual space.

For the common man or woman, however, it helps to know not only that something exists but also perceive how something happens.

The language-user can only follow the clues language gives him/her. This approach is mainly didactic. It assumes less initiation on the part of the terminology, database or dictionary user. Using the assumed knowledge of the reader (lesser), further explanations are given. These definitions or technical notes may be longer and the reader may have to sift through the irrelevant parts but more is ultimately covered. Not only what the term is but what it means in a socially constructed context. Word selection is the product of theoretical choice. Meaning is suggested through reference to a paradigm within a language system. 

finds her/himself in an intermediary position. She/he knows enough about the field to spin off the words but may not have a full grasp of the underlying concepts. Function no.1 is useful to disambiguate similar terms and concepts. This function, though, cannot be fulfilled without substantial understanding, function no. 2, of how things happen. The ESP practitioner therefore must understand something of the text she/he has to wrestle with in order to follow the logical steps of argumentation in the author's original text. ESP communication is not the frequently assumed transparent windowpane coming between technical reality and unknown interlocuteurs. As an actor in the rhetorical process the terminologist should strive to make technology more humane. Information is not knowledge.

\section{Conclusion}

The paradigm shift, from conceptual metalanguage to valid expression in natural language, is the intersection the ESP practitioner must cross. It enables us to perceive the confines of our own perspective.

The theory of objective communication has been eroded by multilingual challenges. Recognized logic forms have position-confined foundations. This paper illustrates how one "objective", concept-oriented field-terminology-is also context dependent. The organization of information by way of word choice, resolution of polysemy, and terminological trees is a subjective application. Polysemy and nomadic metaphors, once delineated, need not be viewed negatively but as a means of fostering communication between contingent fields.

Conventional wisdom holds that the message in ESP texts takes precedence over the means to express it. The former is enhanced while the latter is compressed into metalanguage. This wisdom must be questioned as the goal of scientific rhetoric is, above all, its ability to communicate.

\section{BIBLIOGRAPHY}

ALCTERMS. Alcatel Terminology Database, Alcatel Alsthom Corporate Communications, 54 rue la Boëtie, 75008 Paris.

Bélanger, G. 1991. “Terminologie de l'environnement : une occasion de faire plus”. Terminologies Nouvelles 8, 28-31.

Borgès, J. L. 1966. Other Inquisitions. New York: Washington Square Press.

Corbisier, A. 1994. "The use and function of metaphor in information technology handbooks". ASp 4, 43-60.

Dombrowski, P. M. 1994. "Challenger through the eyes of Feyerabend". Journal of Technical Writing and Communication 24/1, 7-18.

ASp, $7-10 \mid 2012$ 
English, K. 1993. La base de données terminologiques ALCTERMS. L'organisation de la terminologie des telecommunications". Note de recherche pour le DEA de Langue anglaise des spécialités scientifiques et techniques. Université Bordeaux 2.

English, K. 1994. "Building an electronic bibliography into a terminological database". In Gestion électronique de documents et nouvelles technologies en sciences humaines. Centre d'Histoire des Idées dans les Iles Britanniques, Presses de l'Université de Paris-Sorbonne.

Feyerabend, P. 1875. Against Method. London: NLB.

Foucault, M. 1966. Les Mots et les choses. Paris: Gallimard.

Gaudin, F. 1993. Pour une socioterminologie : des problèmes sémantiques aux pratiques institutionnelles. Rouen : Publications de l'Université de Rouen no.182.

Gaudin, F. 1994. “Terminologie de l'environnement : faire plus ...et autrement ?". Terminologies Nouvelles 11 .

Görlach, M. 1994. A Usage Dictionary of Anglicisms in Selected European Languages, International Journal of Lexicography, 7/3, Oxford University Press.

Haraway, D. 1991. Simians, Cyborgs, and Women: the Reinvention of Nature. London: Free Association Books.

Jordan, M. P. 1994. "Toward Plain Language: a guide to paraphrasing complex noun phrases". Journal of Technical Writing and Communication 24/1, 77-96.

Lakoff, G. 1990. Women, Fire, and Dangerous Things. Chicago: The University of Chicago Press.

Queipo, L. 1986. "User expectations of online information”. IEEE Transactions on Professional Communications, 29/4.

Rorty, R. 1991. Objectivity, Relativism and Truth. Cambridge: Cambridge University Press.

Stengers, I. 1987. D'une science à l'autre : des concepts nomades. Paris: Éditions du Seuil.

Tournier, J. 1985. Introduction descriptive à la lexicogénétique de l'anglais contemporain. Paris: Champion - Slatkine.

Woods, W. A. 1975. "What's in a link: Foundations for semantic networks". In Representation and Understanding: Studies in cognitive science. New York: Academic Press.

Wüster, E. 1968. Dictionnaire multilingue de la machine-outil. London: Technical Press.

\section{ABSTRACTS}

The mainstay of terminological work is the identification and organization of dense nominal groups which characterize special languages. Can technical terms, once they are identified, labeled and made monosemic guarantee objective understanding of a technical reality? This article examines this question through the study of point of view, metaphorical motivation, terminological trees and term definition.

L'étude des groupes nominaux denses qui caractérisent la langue de spécialité et leur organisation constitue le gros du travail des terminologues. Mais les termes, une fois identifiés, étiquetés et rendus monosémiques sont-ils les garants d'une compréhension objective de la réalité technique? Cet article examine la question par l'étude du point de vue, la motivation métaphorique des termes, la logique des arbres terminologiques et la fonction de la définition. 
INDEX

Mots-clés: base de données, classification, langue spécialisée, motivation, polysémie, rédaction technique, terminologie, télécommunications

Keywords: database, LSP, technical writing, terminology, polysemy

\section{AUTHOR}

\section{KATHRYN ENGLISH}

Kathryn English est enseignant-chercheur à l'Institut National des Télécommunications. Elle est également responsable de l'enseignement des langues à Alcatel Mobile Communication France et participe à l'élaboration de la base de données terminologiques ALCTERMS. Elle prépare une thèse à l'Université de Paris-Nord sur la motivation métaphorique en terminologie des télécommunications sous la direction de Professeur John Humbley, directeur du Centre de Terminologie et Néologie du CNRS. Kathryn.English@polytechnique.edu 